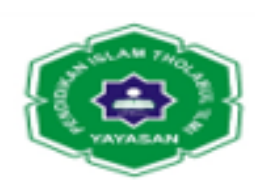

Jurnal Ilmiah METADATA

\title{
PERBANDINGAN POTENSI ANTIOKSIDAN PEMERANGKAPAN NO DAN OH EKSTRAK KULIT BUAH NAGA DENGAN SENYAWA KAEMPFEROL
}

\author{
Elisa Chrismis Novalinda Ginting ${ }^{1}$, Linda Chiuman ${ }^{2)}$ \\ ${ }^{1)}$ Magister Sain Biomed is Fakultas Kedokteran \\ ${ }^{2)}$ Universitas Prima Ind onesia Medan \\ email : ee6543172@gmail.com
}

\begin{abstract}
ABSTRAK
Tujuan dari penelitian ini yaitu menguji aktivitas antioksidan dengan metode pemerangkapan $\mathrm{NO}$ dan $\mathrm{OH}$ dari ekstrak kulit buah naga (EKBN) dan senyawa kaempferol. $\mathrm{NO}$ (nitrat oksida) dan $\mathrm{OH}$ (radikal hidroksil) sangat penting dalam proses penuaan. Kaempferol memiliki nilai IC50 aktivitas antioksidan pemerangkapan NO lebih kecil sekitar 38,68 $\pm 0,48 \mu \mathrm{g} / \mathrm{mL}$ daripada EKBN dengan IC50 sebesar 77,65 $\pm 9,58 \mu \mathrm{g} / \mathrm{mL}$. Hasil uji aktivitas antioksidan pemerangkapan $\mathrm{OH}$, senyawa kaempferol memiliki nilai IC50 lebih rendah yaitu sebesar $29,94 \pm 1,17 \mu \mathrm{g} / \mathrm{mL}$ diband ingkan EKBN nilai IC50 64,63 $\pm 1,26 \mu \mathrm{g} / \mathrm{mL}$. Senyawa pembanding kaempferol memiliki aktivitas antioksidan yang lebih baik dibandingkan dengan EKBN.
\end{abstract}

Kata Kunci : ekstrak kulit buah naga, antioksidan, OH, NO, kaempferol

\section{PENDAHULUAN}

Salah satu dampak dari radikal bebas adalah terjadinya penuaan dini (premature aging) dan kerusakan pada kulit. Kerusakan kulit antara lain terjadi karena adanya sinar ultraviolet (UV), satu dari komponen sinar matahari yang mencapai bumi. Sinar UV ini memiliki efek oksidatif yang dapat menyebabkan peradangan. Efek sinar UV yang bersifat sebagai sumber radikal bebas dapat dicegah oleh antioksidan (Nova, 2012).

Saat kulit terkena sinar matahari, radiasi sinar UV diserap oleh molekulmolekul kulit yang dapat menghasilkan senyawa berbahaya, yang disebut Reactive Oxygen 2 Species (ROS), berakibat kerusakan oksidatif atau stress oksidatif yang mengganggu komponen seluler seperti dinding sel, membran lipid, mitokondria, dan DNA. ROS juga menyebabkan peningkatan radikal bebas dalam sel diantaranya radikal hidroksil $(\mathrm{OH})$ dan nitrat oksida $(\mathrm{NO})$. Kedua radikal bebas tersebut sangat berbahaya bagi sel karena akan berdampak dalam mempercepat proses penuaan dan menunjukkan tanda-tanda penuaan dini (Radi, 2018).

Antioksidan adalah zat penghambat reaksi oksidasi akibat radikal bebas yang dapat menyebabkan kerusakan asam lemak tak jenuh, membran dinding sel, pembuluh darah, basa DNA, dan jaringan lipid sehingga menimbulkan penyakit (Widaystuti, 2010). Antioksidan diketahui melindungi kulit dari ROS dan stres oksidatif dengan melawan radikal bebas melalui beberapa mekanisme.

Berbagai antioksidan yang berasal dari tumbuhan yang telah di uji, salah satunya terdapat pada kulit buah naga yang mengandung senyawa bioaktif yaitu kaempferol dengan aktivitas antioksidan. Kaempferol juga ditemukan pada 


\section{앙 \\ Jurnal Ilmiah METADATA}

tumbuhan lain seperti bawang, teh, anggur, strawberi, selada, dan aloe vera (Singh, 2009 dan Poon, dkk., 2014). Berdasarkan hal tersebut, maka peneliti tertarik untuk melakukan uji potensi antioksidan dalam pemerangkapan $\mathrm{NO}$ dan $\mathrm{OH}$ dari ekstrak kulit buah naga yang dibandingkan dengan senyawa kaempferol. Hal ini perlu dilakukan untuk membuktikan efektifitas kulit buah naga tersebut agar kulit buah naga dapat digunakan sebagai sumber alami dalam menghambat proses penuaan. Lahan pertanian yang baik adalah lahan yang tidak ada masalah dengan hukum dan secara langsung lahan tersebut dapat ditanami tanpa gangguan sehingga tanahnya semakin subur sehingga petani dapat menggarapnya dengan baik (Syah, D, 2019).

\section{METODE PENELITIAN Rancangan Penelitian}

Penelitian ini merupakan penelitian eksperimental laboratorium dengan rancangan acak lengkap.

\section{Waktu dan Tempat Penelitian}

Penelitian dilakukan pada bulan Febuari-Maret 2019 di Laboratorium Herbarium Sekolah Tinggi Ilmu Teknologi Hayati Institut Teknologi Bandung (SITH ITB) dan Laboratorium Biomolecular and Biomedical Research Center (Aretha Medika Utama).

\section{Alat dan Bahan Penelitian}

Alat yang digunakan dalam penelitian ini adalah Multiskan GO Reader, Spatula, Mikropipet (1-10 $\mu 1,50-200 \mu 1,100-1000 \mu 1)$, Tips (1-10 $\mu 1,50-200 \mu 1$, 100-1000 $\mu 1$ ), 96 well-plate, Falcon tube $15 \mathrm{ml}$, Falcon tube $50 \mathrm{ml}$, Analytical Balance, Rotator, Alumunium foil, Tube Effend orf 1,5 ml, Vortex, $\mathrm{pH}$ meter, Tabung Erlenmeyer, Magnetic stirrer and hot plate, Inkubator.

Bahan yang digunakan untuk preparasi sampel berupa ekstrak etanol kulit buah naga merah (Hylocereus polyrhizus), yang diperoleh dari Desa Cijambe, Kecamatan Cijambe, Kabupaten Subang.

\section{Prosedur kerja}

1. Sampel penelitian

2. Sampel yang digunakan adalah kulit buah naga yang diperoleh dari Desa Cijambe, Kecamatan Cijambe, Kabupaten Subang.

3. Pembuatan ekstrak kulit buah naga 6 Kulit buah naga yang sudah dihilangkan daging buahnya dikeringkan dalam lemari pengering pada suhu $45^{\circ} \mathrm{C}$ selama 48 jam. Kulit buah naga yang sudah kering dijadikan serbuk. Pembuatan ekstrak ini menggunakan cara maserasi, yaitu dengan merendam serbuk simplisia kulit buah naga dalam etanol $70 \%$ selama 72 jam, disaring dan diulang 3 kali. Selanjutnya ampas dan filtrat dipisahkan. Filtrat yang diperoleh diuapkan dengan vacuum rotary evaporator pemanas waterbath suhu $70^{\circ} \mathrm{C}$. Proses ini untuk menguapkan etanol sehingga diperoleh ekstrak yang kental (Kemenkes, 2013).

\section{Uji aktivitas antioksidan pemerangkapan NO}

Masukkan $10 \mu \mathrm{l}$ sampel ke dalam well blank dan well sampel. Tambahkan SNP sebanyak $40 \mu \mathrm{l}$ ke dalam well sampel dan well kontrol. Pada well blank, tambahkan $140 \mu \mathrm{l}$ etanol. Pada well control, tambahkan $10 \mu 1$ etanol. Inkubasi plate selama 2 jam pada suhu ruang. Tambahkan larutan Greiss $100 \mu$ l pada well sampel dan well kontrol. Absorbansi diukur menggunakan microplate reader pada $\lambda=546$ 


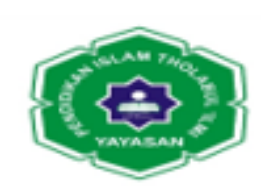

Jurnal Ilmiah METADATA

nm (Parul et al., 2013). \% scavenging activity = absorbansi kontrol-absorbansi sampelabsorbansi kontrol x 100.

\section{Uji aktivitas antioksidan pemerangkapan $\mathrm{OH}$}

Masukkan $2 \mu$ sampel ke dalam well blank dan well sampel. Tambahkan FeCl3-EDTA sebanyak $10 \mu \mathrm{l}$ ke dalam well sampel dan well kontrol. Tambahkan H2O 2 sebanyak $5 \mu \mathrm{l}$ ke dalam well sampel dan well kontrol. Tambahkan $L$ Ascorbic Acid $1 \mathrm{mM}$ sebanyak $5 \mu \mathrm{l} \mathrm{ke}$ dalam well sampel dan well kontrol. Tambahkan deoxyribose sebanyak $10 \mu 1$ ke dalam well sampel dan well kontrol. Pada well blank, tambahkan $120 \mu$ buffer. Pada well control, tambahkan $70 \mu \mathrm{l}$ buffer. Pada well sampel, tambahkan $69 \mu \mathrm{l}$ buffer. Inkubasi plate selama 30 menit pada suhu 37oC. Tambahkan larutan TCA 5\% $25 \mu 1$ pada well sampel dan well kontrol. Tambahkan larutan TBA 1\% $25 \mu$ pada well sampel dan well kontrol. Inkubasi plate selama 30 menit pada suhu $80 \mathrm{oC}$. Absorbansi diukur menggunakan microplate reader pada $\lambda=532 \mathrm{~nm}(\mathrm{Tu}$ et al., 2015). \% scavenging activity = absorbansi kontrol-absorbansi sampelabsorbansi kontrol x 100.

\section{Analisa data}

Data hasil penelitian yang telah dilakukan diolah menggunakan program SPSS dengan uji One-Way dan dilanjutkan Post Hoc Test dengan uji Tukey HSD. Hasil uji aktivitas antioksidan pemerangkapan $\mathrm{NO}$ dan $\mathrm{OH}$ dilanjutkan uji analisis dengan menentukan nilai Inhibition Consentration 50 (IC50).

\section{HASIL PENELITIAN DAN PEMBAHASAN}

Potensi antioksidan pemerangkapan NO dan $\mathrm{OH}$ ekstrak kulit buah naga dan senyawa kaempferol

Kulit buah naga merah kaya akan sumber polyphenol dan antioksidan, dan menurut aktivitas antioksidan kulit buah naga merah lebih besar daripada aktivitas daging buahnya Nurliyana, dkk (2010). Nurliyana, dkk (2010), senyawa polifenol, seperti flavonoid berkorelasi dengan aktivitas antioksidan suatu sampel. Kandungan flavonoid pada ekstrak kulit buah naga merah mengindikasikan bahwa ekstrak tersebut dapat berfungsi sebagai antioksidan alami. Menurut Manuhuruk (2016), bahwa ekstrak 7 kulit buah naga merah (Hylocereus polyrhizus) efektif sebagai antibakteri dan antioksidan alami dengan kandungan senyawa fitokimia yang dimiliki ekstrak tersebut.

Ekstrak kulit buah naga merah memiliki kandungan antioksidan berupa vitamin C, flavonoid, tanin, alkaloid, steroid, dan saponin berdasaran hasil pengujian fotokimia dan FTIR (Noor, 2016). Buah naga mengandung berbagai senyawa aktif diantaranya tiamin, niasin, piridoksin, kobalamin, fenolik, betacyanin, polifenol, karoten, likopen, kaempferol, betacyanin, quercetin dan isorhamnetin dalam melawan radikal bebas (Manihuruk et al., 2017).

Kaemferol dilaporkan memiliki aktivitas antioksidan yang potensi dan dapat bereaksi dengan H202 HOCL, superoksida dan nitrat oksida. Senyawa ini umumnya dicerna sebagai ghikosida. Poliritas ghikosida yang tertinggi menghambat absorpsi, sedangkan poliritas aghikon menengah menunda absorps. Meskipun ini menunjukkan bahwa ghikosida memburuhkan hidrolisis sebelumnya agar aglikon dapat diserat tanpa hidrolisis seperti flavonoid lain, Kaemferol diserap 


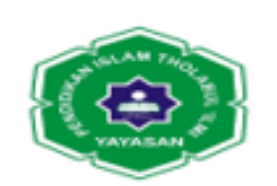

\section{Jurnal Ilmiah METADATA}

di usus. Lipofilisitas Kaemferol memfasilitasi penyerapannya dengan disfusi pasif atau transpor aktif.

Bakteri kolon dapat menghidrolisis glikosida menjadi aglikon dan memecah cincin C3 aglikon untuk membentuk senyawa fenolik sederhana seperti asam 4hidroksifenil asetat, phloroglucinol dan 4- methylphenol, yang dapat diserap atau dikeluarkan dalam feses. Setelah absorpsi, kaempferol dimetabolisme secara luas di hati untuk membentuk bentuk terkonjugasi glukuro dan sulfo. Bentuk terkonjugasi kaempferol ini, beberapa senyawa fenolik yang dihasilkan oleh mikroflora usus besar, kaempferol dan beberapa glikosida kaempferol dapat mencapai sirkulasi sistemik dan jaringan dan kemudian diekskresikan dalam urin. Persentase kaempferol diekskresikan dalam urin telah ditemukan menjadi 1,9\% dan 2,5\% dari jumlah total kaempferol yang dicerna. (Montano, 2011).

Ikatan rangkap pada C2-C3 dalam konjugasi dengan gugus okso di $\mathrm{C} 4$ akibat pemecahan cincin $\mathrm{C} 3$, serta keberadaan gugus hidroksil pada $\mathrm{C} 3, \mathrm{C} 5$ dan $\mathrm{C} 4$, merupakan struktural penting yang terlibat dalam aktivitas antioksidan kaempferol. Kemampuan kaempferol untuk menurunkan kadar superoksida pada konsentrasi rendah dapat memainkan peran penting dalam aktivitas antioksidannya, karena pembentukan anion superoksida diperlukan untuk produksi normal sebagian besar RONS yang terlibat dalam stres oksidatif. Anion superoksida biasanya dikonversi menjadi $\mathrm{H} 2 \mathrm{O} 2$ oleh enzim superoksida dismutase. Dengan adanya logam transisi yang direduksi (mis., ion besi atau tembaga), H2O2 dapat dikonversi menjadi radikal hid roksil yang sangat reaktif. Anion superoksida juga dapat bereaksi dengan nitrat oksida untuk membentuk peroksinitrit. Radikal hidroksil dan peroksinitrit adalah spesies yang sangat reaktif yang diketahui menyebabkan kerusakan DNA, protein, dan lipid. (Montano, 2011).

Penelitian mengenai uji aktivitas antioksidan pemerangkapan $\mathrm{NO}$ dan $\mathrm{OH}$ terhadap kulit buah naga belum pernah dilakukan. Hasil penelitian tersebut berbeda jauh dengan penelitian Lourith \& Kanlayavattanakul (2013) menyatakan bahwa EKBN memiliki aktivitas antioksidan dengan nilai IC50 sebesar 382,04 $\pm 0,42$ $\mu \mathrm{g} / \mathrm{mL}$ berdasarkan uji aktivitas antioksidan ABTS dan 823,58 $\pm 13,25 \mu \mathrm{g} / \mathrm{mL}$ menggunakan metode DPPH. Penelitian lainnya oleh Nurlyana et al. (2010) menunjukkan nilai IC50 EKBM sebesar $0,30 \pm 0,01 \mathrm{mg} / \mathrm{mL}$ dengan metode DPPH. Perbedaan hasil penelitian yang sekarang dengan sebelumnya mungkin dikarenakan adanya perbedaan metode dalam pengujian aktivitas antioksidan EKBM.

Selanjutnya pada pengujian dengan menggunakna metode pemerangkapan DPPH dan $>1 \mu \mathrm{M}$ dengan metode reduksi ABTS, maka senyawa kaempferol memiliki nilai IC50 sebesar $>100 \mu \mathrm{M}$. Perbedaan nilai IC50 dari penelitian sebelumnya dengan penelitian sekarang dikarenakan metode pengujian yang digunakan berbeda. Hasil penelitian mengenai aktivitas pemerangkapan radikal bebas NO oleh EKBN dan senyawa kaempferol (tabel 4.3), keduanya menunjukkan aktivitas antioksid an yang baik. Aktivitas antioksid an pemerangkapan NO tertinggi pada konsentrasi $66,67 \mu \mathrm{g} / \mathrm{mL}$ oleh EKBN maupun kaempferol, masing-masing sebesar 44,71 $22,91 \%$ dan $66,74 \pm 0,62 \%$. Begitu juga halnya dengan aktivitas antioksidan pemerangkapan $\mathrm{OH}$ dimana EKBN dan kaempferol mempunyai 


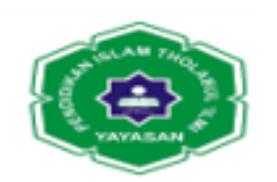

\section{Jurnal Ilmiah METADATA}

aktivitas antioksidan paling baik pada konsentrasi tertinggi yaitu $26,67 \mu \mathrm{g} / \mathrm{mL}$ sebesar $21,41 \pm 0,28 \%$ dan $44,77 \pm 1,66 \%$.

Widowati, Ed. (2017) mengklasifikasikan kekuatan antioksidan berdasarkan nilai IC50 bahwa suatu senyawa memiliki antioksidan yang sangat kuat jika IC50 $<50$ ppm, kuat apabila IC50 50-100 ppm, sedang apabila IC50 100-150 ppm, dan lemah bila IC50 151-200 ppm atau lebih. Berdasarkan klasifikasi tersebut dapat disimpulkan bahwa IC50 dari EKBN dan kaempferol memiliki potensi antioksidan yang kuat.

\section{Konsentrasi optimal ekstrak kulit buah naga yang mempunyai aktivitas antioksidan dalam pemerangkapan radikal bebas NO dan $\mathrm{OH}$}

Radikal bebas dikenal sebagai atom atau molekul yang sangat reaktif dengan satu atau lebih elektron yang tidak berpasangan di orbita luarnya dan dapat dibentuk ketika oksigen berinteraksi dengan molekul tertentu. Radikal ini dapat diproduksi dalam sel dengan kehilangan atau menerima satu elektron sehingga bertindak sebagai oksidan atau reduktor. Istilah Reactive Oxigen Species (ROS) dan Reactive Nitrogen Species (RNS), masing-masing mengacu pada turunan radikal dan nonradikal oksigen dan nitrogen. Reactive Oxygen and Nitrogen Species (RONS) diproduksi oleh semua sel aerobik dan memainkan peran penting dalam penuaan serta penyakit terkait usia. Generasi RONS tidak hanya terbatas untuk menentukan efek merusak tetapi juga terlibat dalam ekstraksi energi dari molekul organik dan pertahanan kekebalan tubuh (Radi, dkk, 2018).

Sumber RONS endogen termasuk nicotinamide adenine dinucleotide phosphate (NADPH) oksidase, myeloperoxidase (MPO), lipoksigenase, dan angiotensin II. NADPH oksidase adalah sumber lazim dari anion superoksida radikal $(\mathrm{O} 2 \bullet$ ) yang dibentuk oleh reduksi satu elektron dari oksigen molekuler, dengan elektron yang disuplai oleh NADPH selama respirasi sel. Sebagian besar $\mathrm{O} 2$ - dilepaskan ke dalam hidrogen peroksida (H2O2) oleh superoksida dismutase (SOD). H2O2 bukan radikal bebas karena tidak memiliki elektron yang tidak berpasangan, tetapi mampu membentuk ion hidroksil ROS yang sangat reaktif $(\mathrm{OH} \bullet)($ Radi, 2018).

Radikal hid roksil sangat reaktif, terutama dengan fosfolipid dalam membran sel dan protein. Dalam neutrofil, $\mathrm{H} 2 \mathrm{O} 2$ dengan klorida dan MPO dapat dikonversi menjadi asam hipoklorida, yaitu suatu ROS yang secara khusus merusak protein seluler. Nitrit oksida (NO) diproduksi dari L-arginin oleh tiga isoform utama nitrat oksida sintase (NOS): 1) epithelial NOS, terkait dengan vasodilatasi dan regulasi vaskular; 2) NOS neuronal, terkait dengan pensinyalan intraseluler; dan 3) NOS yang diinduksi, diaktifkan sebagai respons terhad ap berbagai sinyal endotoksin atau sitokin. Akhirnya, O2 dapat bereaksi dengan NO untuk membentuk molekul lain yang relatif reaktif, yaitu peroxynitrite (ONOO-) (Radi, 2018).

Salah satu penyebab ROS dan RONS adalah paparan sinar UV yang berlebihan dan mempengaruhi kulit. Penampilan kulit dapat bervariasi antara individu dan tergantung pada kecenderungan tingkat melanisasi individu, frekuensi serta durasi paparan UV. Paparan sinar matahari yang dikenal photoaging, meningkatkan risiko perkembangan kanker kulit. Sensitivitas terhadap sinar matahari tergantung pada pigmentasi kulit, yaitu individu dengan pigmentasi tinggi umumnya kurang sensitif dibandingkan dengan individu yang memiliki kulit lebih 


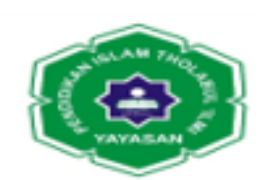

\section{Jurnal Ilmiah METADATA}

jernih. Akibatnya, ada penebalan dan pengeringan kulit, pembentukan kerutan, melanosis, telangiectasias serta lesi jinak, premalignant dan ganas.

Sinar ultraviolet (UV) terbagi atas UVA dan UVB. Radiasi UVB merupakan penyebab paling terkait dengan pengembangan kanker kulit. DNA menyerap radiasi UVB, yang mengarah ke multiplikasi dalam transkripsi rantai DNA. UVA menghasilkan lebih banyak stres oksidatif, terutama bertanggung jawab atas peroksidasi lipid. Selain menyebabkan perubahan DNA, radiasi UVA juga mampu menghambat perbaikan DNA. Radiasi UV dapat mempengaruhi sampai lapisan kulit paling dalam. Proses ini yang menyebabkan terjadinya penuaan pada kulit.

Stres oksidatif yang menjadi proses kunci dasar photoaging dan photocarcinogenesis dapat dicegah dengan antioksidan alami dari suatu tanaman. Senyawa alami yang dimaksud seperti vitamin, karotenoid, terpenoid, polifenol, alkaloid, tanin, saponin dan senyawa lainnya yang memiliki aktivitas antioksidan. Beberapa senyawa seperti xanthone, asam galat, $\beta$-caroten, eugenol, myricetin, coumaric acid juga berperan sebagai anti-aging. Buah naga mengandung berbagai senyawa aktif diantaranya tiamin, niasin, piridoksin, kobalamin, fenolik, betacyanin, polifenol, karoten, likopen, kaempferol, betacyanin, quercetin dan isorhamnetin dalam melawan radikal bebas (Manihuruk, ddk, 2017).

Hasil penelitian mengenai aktivitas pemerangkapan radikal bebas NO oleh EKBN menunjukkan aktivitas antioksidan. Aktivitas antioksidan pemerangkapan NO tertinggi pad a konsentrasi $66,67 \mu \mathrm{g} / \mathrm{mL}$. Aktivitas antioksidan pemerangkapan $\mathrm{OH}$ oleh EKBN mempunyai aktivitas antioksidan paling baik pada konsentrasi tertinggi yaitu $26,67 \mu \mathrm{g} / \mathrm{mL}$ sebesar $21,41 \pm 0,28 \%$ dan $44,77 \pm 1,66 \%$.

Perbandingan potensi antioksidan ekstrak kulit buah naga dalam pemerangkapan radikal bebas NO dan $\mathrm{OH}$ dengan senyawa kaempferol

Hasil penelitian mengenai aktivitas pemerangkapan radikal bebas NO oleh EKBN dan senyawa kaempferol (tabel 4.3), keduanya menunjukkan aktivitas antioksidan yang baik. Aktivitas antioksidan pemerangkapan NO tertinggi pada konsentrasi $66,67 \mu \mathrm{g} / \mathrm{mL}$ oleh EKBN maupun kaempferol, masing-masing sebesar $44,71 \pm 2,91 \%$ dan $66,74 \pm 0,62 \%$. Begitu juga halnya dengan aktivitas antioksidan pemerangkapan $\mathrm{OH}$ dimana EKBN dan kaempferol mempunyai aktivitas antioksidan paling baik pada konsentrasi tertinggi yaitu $26,67 \mu \mathrm{g} / \mathrm{mL}$ sebesar $21,41 \pm 0,28 \%$ dan $44,77 \pm 1,66 \%$.

Nilai IC50 pemerangkapan NO dari kaempferol memiliki IC50 sebesar $38,68 \pm 0,48 \mu \mathrm{g} / \mathrm{mL}$ lebih kecil dibandingkan dengan EKBN yang memiliki nilai IC50 EKBN 77,65 $\pm 9,58 \mu \mathrm{g} / \mathrm{mL}$. Aktivitas pemerangkapan $\mathrm{OH}$ menunjukkan hasil setara dengan 10 antioksidan pemerangkapan NO dimana nilai IC50 sebesar EKBN $64,63 \pm 1,26 \mu \mathrm{g} / \mathrm{mL}$ dan kaempferol sebesar 29,94 $\pm 1,17 \mu \mathrm{g} / \mathrm{mL}$.

Widowati, (2017) mengklasifikasikan kekuatan antioksid an berdasarkan nilai IC50 bahwa suatu senyawa memiliki antioksidan yang sangat kuat jika IC50<50 ppm, kuat apabila IC50 50-100 ppm, sedang apabila IC50 100-150 ppm, dan lemah bila IC50 151-200 ppm atau lebih. Berdasarkan klasifikasi tersebut dapat disimpulkan bahwa IC50 dari EKBN dan kaempferol memiliki aktivitas antioksidan yang kuat. 


\section{(ㄷ) \\ Jurnal Ilmiah METADATA}

\section{KESIMPULAN}

1. EKBN dan kaempferol memiliki aktivitas antioksidan pemerangkapan $\mathrm{NO}$ dan $\mathrm{OH}$.

2. Aktivitas antioksidan pemerangkapan NO EKBN paling berpotensi pada konsentrasi $66,67 \mu \mathrm{g} / \mathrm{mL}$ sebesar $44,71 \pm 2,91 \%$ dan aktivitas antioksidan pemerangkapan $\mathrm{OH}$ EKBN terbaik pada konsentrasi $26,67 \mu \mathrm{g} / \mathrm{mL}$ sebesar $21,41 \pm 0,28 \%$.

3. Perbandingan aktivitas antioksidan pemerangkapan $\mathrm{NO}$ dan $\mathrm{OH}$ dilihat berdasarkan nilai IC50 menunjukkan bahwa aktivitas antioksidan kaempferol yang lebih efektif dibandingkan EKBN.

\section{DAFTAR PUSTAKA}

Choo, W S. \& W K Yong. 2011. Antioxidant properties of two species of Hylocereus fruits. Advances in Applied Science Research, 2 (3): 418-422.

Calderon-Montano, J.M. 2011. A Review on the Dietary Flavonoid Kaempferol. Mini-Reviews in Medicinal Chemistry, 11:318-319.

Hery, Winarsi. (2007). Antioksidan Alami dan Radikal Bebas : Potensi dan Aplikasinya Dalam Kesehatan. Kanisius Media. Jakarta.

Manihuruk. (Ed). 2017. Effectiveness of the Red Dragon Fruit (Hylocereus polyrhizus) Peel Extract as the Colorant, Antioxidant, and Antimicrobial on Beef Sausage. Jurnal Media Peternakan, 4 0(1) : 50-51.

Nurliyana (Ed). 2010. Antioxidant study of pulps and peels of dragon fruits: a comparative study. International Food Research Journal, 17: 368-372.

Noor, Ilham Muhammad, (Ed). 2016. Indentifikasi Kandungan Ekstrak Kulit Buah Naga Merah Menggunakan Fourier Transform Infrared (FTIR) dan Fitokimia. Journal of Aceh Physics Society (JAcPS), Vol. 5, No. 1 pp.14-16.

Radi, R. 2018. Oxygen radicals, nitric oxide, and peroxynitrite: Redox pathways in molecular medicine. PNAS, 115: 5840-5846.

Singh, G. 2009. Can We Prevent Skin Aging. Indian J Dermatol Venereol Leprol, $75(5): 450 \mathrm{p}$.

Widyastuti, Niken. 2010. Pengukuran Aktivitas Antioksidan Dengan Metode Cuprac, Dpph, Dan Frap Serta Korelasinya Dengan Fenol Dan Flavonoid Pada Enam Tanaman. Departemen Kimia Fakultas Matematika Dan Ilmu Pengetahuan Alam. Institut Pertanian Bogor. Skripsi.

Syah, D. (2019). SUATU TINJAUAN HUKUM TENTANG BAGI HASIL ATAS TANAH PERTANIAN ANTARA PEMILIK TANAH DENGAN PETANI. Jurnal Ilmiah METADATA, 1(3), 127-146. 